Extrême-Orient Extrême-Occident

\section{Extrême-Orient Extrême-Occident}

35 | 2013

Les astres et le destin. Astrologie et divination en Asie orientale

\title{
The Assimilation of Astrology in the Tibetan Bon Religion
}

L'assimilation de l'astrologie dans la religion tibétaine Bon

\section{Charles Ramble}

\section{(2) OpenEdition \\ Journals}

Electronic version

URL: http://journals.openedition.org/extremeorient/288

DOI: $10.4000 /$ extremeorient.288

ISSN: 2108-7105

\section{Publisher}

Presses universitaires de Vincennes

\section{Printed version}

Date of publication: 1 May 2013

Number of pages: 199-232

ISBN: 978-2-84292-367-9

ISSN: 0754-5010

Electronic reference

Charles Ramble, «The Assimilation of Astrology in the Tibetan Bon Religion », Extrême-Orient ExtrêmeOccident [Online], 35 | 2013, Online since 01 May 2016, connection on 30 April 2019. URL : http:// journals.openedition.org/extremeorient/288 ; DOI : 10.4000/extremeorient.288 


\title{
The Assimilation of Astrology in the Tibetan Bon Religion
}

\author{
Charles Ramble
}

\section{Introduction}

One of the earliest examples of Tibetan literature is the manuscript classified as "Pelliot tibétain 1288," commonly referred to as the Annals. A few lines after the beginning of this work we find the following words: "Year of the Dog (650). The body of the great father, kept in the funerary chamber [...]" ${ }^{11}$ Two things are to be noted from this, and subsequent, entries. The first is that the Tibetans of the time were using a twelve-year animal cycle for purposes of dating. The other is that they had not yet adopted the five elements to combine with these animals in order to produce a sexagenary cycle.

Together with the Dunhuang collection - to which the Annals belongand other lesser manuscript collections from the Silk Road, the oldest Tibetan material available to us is that which is recorded on stone stelae. One of these pillars announces a peace treaty between Tibet and China that was concluded in 822 , and the first of two oaths sworn in Chang'an. The text of the treaty opens as follows: "The tenth day of the first winter month of the female iron bull year; the name of the year in Great Tibet being the seventh year of Eternal Happiness, and the name of the year in Great China being the first Cang keng year [...]."2 The date given here contains three features of particular note. First, the animal from the twelve-year cycle (bull) has been combined with an element (iron), enabling a precise dating within a sixty-year span. The second point concerns the identification of the year as "the seventh year of eternal happiness." This is a highly unusual instance of Tibetans following the Chinese practice of identifying

1. Bacot et al. 1940: 30 .

2. Uray 1984: 347. 
a year in terms of the reign of a new emperor (tsenpo; btsan po). ${ }^{3} 822$ was the first year of the reign of the Emperor Cang keng, and it was also the seventh year of the reign of Tibet's penultimate emperor, Tri Detsugtsen (Khri lDe gtsug btsan), better known as Repacen (Ral pa can; r. 815-838). The Hungarian scholar Géza Uray has suggested that these two unusual features may have been adopted for dating purposes because of the special circumstances, "in order to emphasize the equal rank of the two states that was for the first time acknowledged by China precisely in the 821-822 treaty." 4

The third feature worth noting is the identification of the day and the month. The system adopted here is the one that is universally attested in Tibetan writing for the dynastic period (c. 627-846). The year was divided into four seasons, and each of these seasons into three parts: early ( $r a w a ; r a b a)$, middle (dringwa; 'bring ba) and late (thachung; tha chung). This practice would in time come to be superseded by three other systems, of which more will be said below.

From the earliest times, then, it is clear that the Tibetan calendrical system was a plural one, combining a number of different schemes. Another feature that becomes apparent from the outset is the intimate implication of time-reckoning and temporality with issues of identity and politics.

\section{Outline of the article}

There is nothing intrinsically Buddhist about the Tibetan calendrical or astrological systems. Indeed, a Tibetan conviction that Kālacakra astrology represented an immutable truth taught by the Buddha led to the preservation of dramatic inaccuracies. However, the discourse in which these systems are conveyed, and the narratives attached to them have a markedly Buddhist character. In the 17th century no less a figure than the Regent of the Fifth Dalai Lama, Desi Sangye Gyatso (sDe srid Sangs rgyas rgya mtsho), claimed that elemental divination was a legitimate path for the attainment of Buddhahood. ${ }^{5}$ The transformations that the calendar underwent over the course of time attest to its potential political capital, and its perception as a locus of religious or political identity - as prefigured in the examples from the imperial period cited above. In this article I shall be concerned less with the science and mathematics of the Tibetan astrological system than the way in which this system is

3. Tibetan terms and names will be presented throughout in roughly phonetic transcription. At their first appearance they will be followed by the orthographic form according to the Wylie system of transliteration. Titles and short excerpts from texts will be presented in footnotes in Wylie transliteration only.

4. Uray 1984: 348.

5. Schuh 1973a: 17. 
modified in different cultural environments. The environment with which I shall be particularly concerned here is the Tibetan Bon religion. Although the appropriation of the calendrical and astrological schemes in a number of religious or regional Tibetan contexts has been discussed in a few studies (notably Schuh 1973 and Hobbs 2012), the assimilation of these systems within the Bon religion has never, as far as I am aware, been the subject of investigation.

The term "assimilation" will be used in this article to denote two different, but related, processes. On the one hand, it refers to the process whereby the Bonpos have adopted the Kālacakra complex and made it their own. Secondly, it describes the educational curriculum in the context of which trainee Bonpo monks learn the principles and techniques of astrology and divination.

\section{The Kālacakra}

The examples of dating given at the beginning of this article can leave us in no doubt about the importance of an early Chinese influence. ${ }^{6}$ Even more important for the development of the Tibetan astrological tradition was an Indian system known as the Kālacakra, the "Wheel of Time." The end of the Tibetan Empire in 846 - the year that saw the assassination of the last dynastic ruler-was followed by more than a century during which political power was fragmented, and Buddhism bereft of the royal and state patronage it had previously enjoyed. The emergence of a Buddhist monarchy in Western Tibet in the late tenth century brought with it a surge of activity during which Buddhist texts were rendered into Tibetan from Sanskrit. The translation of certain categories of works had been expressly banned during the dynastic period. The production of such works continued to proliferate in India, and literature from this late phase - the so-called yogini tantras - were now especially favoured. The Kālacakra was a late example of this category of literature. Several translations of the cycle were made, but for the Tibetans the landmark date for the arrival of the system in their country was 1027 . (In fact, the arrival date is probably a fiction; it coincides rather too conveniently with the first year of the system's sixty-year cycle.) Buddhists regard the Kālacakra as an esoteric teaching of Shākyamuni himself, who preached it in the south-east Indian town of Dhānyakațaka. The main recipient was a certain Sucandra, king of the mythical land of Shambhala, where it passed though numerous generations of royalty before it was eventually transmitted to an Indian Buddhist master.

6. It should be noted, however, that the origin of the twelve-year annual cycle may been Turkish or Uighur rather than Chinese (Uray 1984: 344; cf. Hobbs 2012: 132, fn. 52). 


\section{Structure of the Kālacakra ${ }^{7}$}

The Kālacakra cycle consists of five chapters, of which the first - the "Outer Kālacakra" - contains the system of astrological reckoning. The original, fulllength Kālacakratantra is believed to have been lost in India, and what came to Tibet was an abridged version known as the Laghu-Kālacakratantra (Tib. Dügyü; bsDus rgyud), together with a commentary entitled Vimalaprabha. Although there is clear evidence that the Kālacakra system of calculation was in use in Tibet as early as the twelfth century - notably in a calendrical system developed by Dragpa Gyaltsen (Grags pa rgyal mtshan; 1147-1216), this adoption was partial, ${ }^{8}$ and it was not until the time of Phagpa ('Phags pa), the hierarch of the Sakya (Sa skya) school of Buddhism, that the calendar became binding for the entirety of Tibet. Phagpa (1235-1280), who was the imperial preceptor (Chinese ti-shih) to Qubilai Khan, developed the so-called Sakya-Yuan calendar by adapting the Chinese sexegenary cycle to that of the Kâlacakra so that the starting date of the cycle was not the Wood Rat year-as in the Chinese scheme - but the Fire Hare year, three years later. The name of this year, Rabjung (Rab'byung; Sk. Brihaspati) came to denote the cycle as a whole. Phagpa advanced the start of the year from the spring, when the Kālacakra's year begins, to coincide with the Chinese New year, on the grounds that this was the beginning of the Mongolian year. Even today, Tibetan almanacs refer to the months in this sequence as "Mongolian months" (horda; hor zla). Like the Chinese calendar, the Sakya-Yuan calendar is luni-solar, which means that certain years require the intercalation of a thirteenth month. Unlike the Chinese system, however, the Tibetan calendar determines these intercalations on the basis of Kālacakra-based calculations, with the result that the Chinese and Tibetan New Year do not always coincide.

Phags pa's intention was undoubtedly a dual one. Namely, that on the one hand the common ground between Tibet and China regarding year-counting and yearbeginning should be emphasised and made binding, while on the other he wants to make it clear that he is creating a non-Chinese calendrical system that follows the tradition of the Kālacakra. This distinction must doubtless be seen as a delicate political matter. ${ }^{9}$

7. The following summary of the history of the Kālacakra is substantially drawn from Schuh 1973a: 16ff.

8. Schuh 1973a: 5 .

9. Schuh 1973a: 6; my translation. 
A further indication of the synthetic nature of the calendar is given by the official Tibetan almanacs, which begin not in the first but in the third month, in acknowledgement of their debt to the Kālacakra.

The tropical year is the length of time taken for the sun to return to the same point - such as the spring equinox - in the cycle of seasons. The sidereal year, by contrast, is the length of time it takes for the sun to complete its apparent cycle along the ecliptic and through the twelve constellations of the zodiac. The tropical year lags behind the sidereal year by approximately twenty minutes. According to the Kâlacakra, at the beginning of the year (that is, the third month in the Sakya-Yuan calendar) the sun should enter the sign of Meșa (Aries) and at the same time reach the spring equinox. However, because of the growing discrepancy between the sidereal and tropical years - the phenomenon known as the precession of the equinoxes - it was observed in the 15th century that the equinox occurred 23 days before the sun entered Aries. The Tibetans'conclusion was not that the Kālacakra reckoning system was wrong (it was, after all, the word of the Buddha), but that the discrepancy was caused by Tibet being located to the east of India. Nevertheless, different systems of calculation were developed after this time in order to correct the discrepancy. ${ }^{10}$ Although this is not our main concern here, there is some evidence - mentioned below-that certain Bonpo scholars also developed such corrective systems.

\section{The Bon religion of Tibet-a brief introduction}

In addition to the growing body of research on specific aspects of Bon, there are a number of works of a more general character, notably Karmay 1998 (1975), Snellgrove 1967 (Introduction), Kvaerne 1995 (Introduction) and the articles contained in Karmay and Watt (eds) 2007. From a historical point of view, Bon appears to be a confluence of religious and cultural currents from a range of periods and geographical provenances, notably India, China, Central Asia and Tibet itself. The effort to organise these different strands into a coherent system has been undertaken by several Bonpo scholars over the centuries, and though there are several classificatory schemes, the tradition as a whole is referred to as Yungdrung Bon, "Eternal Bon." For followers of Bon-the Bonpos - the corpus of doctrines and practices that have been recognised as Yungdrung Bon is regarded as the teaching of Shenrab Miwo (gShen rab mi bo), the founder of the religion. Shenrab is believed by the Bonpos to have lived many thousands of years ago, while Shākyamuni, the historical Buddha, is regarded as a later incarnation of one of his disciples, whence - as we shall

10. Schuh 1973: 21; Hobbs 2012: 147-157. 
see below - the similarity in many aspects of the two religions. For Buddhists, by contrast, this similarity is due to the Bonpos'having copied and modified Buddhist works. While it is surely the case that much in Bon literature owes a debt to Indian Buddhism, there is incontrovertible evidence to show that Buddhist writers also borrowed from Bonpo sources. ${ }^{11}$

The concentration of Bonpo monasteries and communities in the eastern part of Tibet is attributed to the Buddhist persecution of the religion in Central Tibet during the imperial period. However, a number of important Bonpo families were represented in Central Tibet, among them the Dru (Bru). It was a scion of this family, Sherab Gyaltsen the Nonpareil (mNyam med Shes rab rgyal mtshan, 1356-1415) who, in 1405, founded the monastery of Menri (sMan ri) near the present-day town of Shigatse (gZhis ka rtse) and made it a centre for a systematised, monastic Bon tradition. The other Central Tibetan monastery that is of particular importance to us is Yungdrungling (gYung drung gling), which was founded in 1834 by Nangtön Dawa Gyaltsen (sNang ston Zla ba rgyal mtshan, 1796-?). Located six hours'walk away from Menri, Yungdrungling would become a centre for the study of dialectics and debate. Both were destroyed during the Cultural Revolution, but were re-established by Bonpo exiles as a single foundation in India during the 1960s. It is with the teaching of astrology and divination in these monasteries, both in Tibet and in India, that this article will be primarily concerned.

\section{Transmission of the astrological tradition within the Bonpo system of monastic education}

As in the case of the Gelugpa school, the highest academic rank among the Bonpos is that of geshe (dge bshes), which is generally considered to correspond to the degree of Doctor of Divinity in the Western scholarly hierarchy. The programme of training for this degree was very different in pre-1959 Tibet from its present form in exile. The range of materials that students were expected to master was more limited, and there was very little by way of an actual curriculum. To a great extent, monks dropped in and out of classes at liberty, and teachings on more esoteric subjects - such as the higher tantras and the systems of the "Great Perfection" (Dzogchen; rDzogs chen) could be obtained only by private arrangement with a senior monk or teacher.

The educational trajectory followed by Tenzin Namdak (bsTan'dzin rnam dag), the Senior Teacher (lopön; slob dpon) of the Bonpos, who is largely responsible for the modern curriculum, is illustrative of the haphazard nature

11. Blondeau 1984; He 2012. 
of this education. ${ }^{12}$ Born in Eastern Tibet, he trained with his uncle as a mural painter and learned to read and write with an older monk who adopted him as a protégé. Spontaneous and haphazard generosity of this sort would have been a critical factor in the education of a novice from a poor background who had no means to pay for his own maintenance in a monastery. At the age of sixteen he accompanied a team of painters to west-central Tibet to decorate the walls of a newly-built hall at Yungdrungling monastery, and when the contract was completed at the end of three years he determined to pursue his real interest - the study of astrology and divination. Although he managed to obtain some basic training at the monastery itself, the individual generally acknowledged to be the expert in this domain had retired from Menri monastery a few years previously and was living the life of a hermit at a cave near a large lake, Namtso, several days'walk away.

Gangri Pönlob Tshultrim Gyaltsen (Gangs ri dpon slob Tshul khrims rgyal mtshan) refused at first to accept Tenzin Namdak as his disciple on the grounds that he had devoted the previous eighteen years of his life to full-time teaching and administration, and wanted now to dedicate the remainder of his life to solitary meditation. But Tenzin Namdak's persistence prevailed - Gangri Pönlob agreed to teach him in exchange for carrying out certain painting tasks - and he began his apprenticeship in earnest with a close study of a recently-compiled treatise on Sino-Tibetan divination by Khedrub Lungtog Gyatso (mKhas grub Lung rtogs rgya mtsho). This was followed by a study of Indian astrology, for which the manual he used was a work by Khenchen Nyima Tenzin (mKhan chen Nyi ma bstan'dzin), the twenty-third abbot of Menri Monastery who had lived in the nineteenth century. We shall have more to say about these two works and their authors in due course.

Tenzin Namdak received no material support from his master, but he was able to keep himself thanks to painting commissions from a wealthy Bon monastery a relatively short distance (two days'walk) from his cave. After four years of training, Gangri Pönlob sent his young ward to Menri monastery, where he embarked on a study of other subjects — particularly philosophy and dialectics - while at the same time carrying out a wide variety of administrative and pedagogical duties.

12. The following information concerning Tenzin Namdak's educational trajectory and the development of the monastic curriculum is based on interviews conducted in July 2012. I am indebted to Tenzin Namdak Rinpoche for taking the time to relate these events. I would also like to express my sincere gratitude to Khenpo Tenpa Yungdrung for his patience in helping me with the numerous difficulties I encountered with the texts presented here. Finally, I am grateful to the anonymous reviewer of an earlier draft of this article for numerous helpful criticisms and suggestions. 
When Tenzin Namdak and a few properly-educated Bonpo lamas found themselves in India amid the general exodus that had followed the Dalai Lama into exile in 1959, the annihilation of the Bonpo monastic system was a very real possibility. If the Bonpos had been a minority in Tibet, their proportion of the exile community was even smaller, at an estimated one per cent of the refugees. A substantial part of these early years was spent in trying to assemble a corpus of Bonpo scriptural works, most of which had remained behind in Tibet. The majority of these would not survive the coming Cultural Revolution. Manuscripts were borrowed from the Bonpo monasteries of highland Nepal and reproduced in India. The publication of these works was made possible thanks to a programme implemented by the US Library of Congress, which resulted in the production of small print-runs of endangered works under the direction of the late scholar Ellis Gene Smith. Tenzin Namdak was engaged on this project for several years, and one of the works he selected for reproduction was a two-volume treatise on Indo-Tibetan astrology by the Bonpo polymath Khyungtrul Jigme Namkhai Dorje (Khyung sprul'Jigs med nam mkha'i rdo rje; 1897-1956), a work of remarkable density and sophistication written when the author was only 28.

The Bonpo leaders'efforts to prevent the dispersal of their coreligionists into the primarily Buddhist refugee camps of South India were successful, and 1967 saw the establishment of the main Bonpo centre in exile — and, shortly thereafter, the first Bonpo monastery. This flourishing monastery, located at Dolanji, near Shimla in Himachal Pradesh, is regarded as a translocated conflation of the Tibetan establishments of Menri and Yungdrungling. The current abbot is the thirty-third throne-holder of the Menri abbatial succession.

The geshe curriculum that Tenzin Namdak and his peers devised was envisaged as a nine-year course of study. The proposal was submitted to the Central Tibetan Administration (sometimes referred to as the Tibetan Government-in-Exile) in 1977, and duly approved. For the first group of monks to complete this course in 1986 the period of study lasted the proposed nine years. However, new components were added over time and the course at it stands now takes a full thirteen years to complete.

Philosophy and dialectics comprise the backbone of the curriculum, as indeed they do in the geshe training system of the Gelugpa school. In contrast with the latter, however, the Bonpo scheme accords a very important place to the sciences.

In spite of the vast literary output of the Tibetans, the production of literature was the province of a relatively small proportion of scholarly monks. Education was a substantially oral affair, with a great deal of emphasis on the memorisation of scriptures and the oral formulation of sophisticated arguments based on this ingested knowledge. Some of the most highly educated monks were quite unable 
to write, and urgent steps were taken to rectify this situation in the early years of exile in India, where the inability to write was misconstrued as educational or intellectual deficiency. In fact, in Tibet, too obvious an interest in literacy and numeracy for their own sake were looked on askance by the most refined intellects as indicative of an aspiration to be a tsedrung (rtse drung), one of the group of monkish clerics who served the government in various capacities, including the army. Literacy had little to do with scholarship; indeed, good handwriting was rather associated with the worldly skills (along with administrative capability and numeracy) that qualified individuals for government service.

While this is not the place to undertake a detailed presentation of the modern curriculum for the Bonpos'geshe degree, ${ }^{13}$ it is worth at least examining the place that astrology and divination have in their higher educational system. ${ }^{14}$

The category of "cultural sciences" or, more simply "sciences" (rigne; rig gnas) is a long-established notion in Tibet that is derived from Indian Buddhist literature. The original set of five, elaborated in the fifth-century Sanskrit Mahāyānasūtralaṃkara, comprised language, medicine, technology, logic and epistemology, and "inner science" (that is, Buddhism). ${ }^{15}$

In Tibet, this original set was refracted into five major and five minor sciences. These were, respectively, language, syllogisms, medicine, technology and Buddhism; and, for the five minor branches, grammar, poetics, metrics, drama and lexicography. This set of ten, which was formulated by the scholar Sakya Paṇdita (Sa skya Paṇdita; 1182-1251) ${ }^{16}$ found numerous variants, and in a number of these we find the science of astrology. The corresponding list in the Bon tradition comprises the following five major sciences: technology, grammar, "outer sciences," "inner sciences," and medicine. The minor sciences are: poetics, lexicography, astrology, drama and metrics. Sino-Tibetan divination or elemental divination (nagtsi; nag rtsis) does not feature separately, but it is included among the so-called "outer sciences." While astrology is also regarded as being one of these "outer sciences," it is accorded a special place among the minor sciences. It should be noted that the Bonpos are by no means unique in according to astrology the status of a science: a more widespread scheme than that formulated by Sakya Paṇita has, for the major sciences, technology, medicine, grammar (sic; here a major science as in the case of the Bonpos), logic and "inner science"; and for the minor five, poetics, lexicography, metrics, drama and astrology. ${ }^{17}$

13. For the dialectics component of the Bonpos'geshe curriculum, see Cech 1986.

14. The following summary of the geshe programme of study is based on dPal ldan.

15. Van der Kuijp 1996: 393.

16. The list follows that given in Cabezón and Jackson 1996: 18.

17. Dung dkar tshig mdzod: 1900. 
The memorisation of vast quantities of scripture still plays a significant part in the education of Tibetan monks, but the first year of the exile geshe curriculum begins by establishing a solid foundation in grammar and spelling. Tibetan orthography is complex, because the combinations of letters bear little resemblance to their pronunciation, and most Tibetans are terrible spellers. The course book that is used is yet another pedagogical work by Khyungtrul, the "Lamp of the Phenomenal World" (Srid pa'i sgron me) and competence in spelling and handwriting is ensured by weekly tests in dictation. This introductory year is known as the "elementary class," düdra (Tib. bsdus grwa), a term that literally means "collected topics." The second year sees the introduction of syllogism (tagrig; rtags rigs) and grammar. This establishes the fundamental pattern up to the tenth year of the course: the morning teaching session is dedicated to the "core," broadly philosophical topics, while the afternoons are devoted to the sciences. Grammar (as one of the major sciences) is taught in the afternoon. In the third year, morning classes consist of teaching in epistemology (tshema; tshad ma) and those of the afternoon to poetics - again, one of the major sciences. The Tibetan tradition of poetics (nyen-ngag; snyan ngag) was developed in the thirteenth century in emulation of the Indian kavya tradition of ornate poetry, but the textbook used by the Bonpos was one compiled by Gangri Lobpön Tshultrim Gyaltsen, the very hermit who had taught Tenzin Namdak in his formative years in the cave.

It is in the fourth and fifth years of their curriculum that Bonpos broach the topics of elemental divination and astrology, and we shall return to this period after a brief overview of the remainder of the course. The sixth and seventh years cover the study of the Perfections (Prajñāpāramitā), while the afternoon science period is devoted to iconometry. Insofar as it deals with the design of mandalas and stupas, the course belongs to the science of technology or construction (zowa; bzo ba). As in the case of astrology and divination, examination of this course component is based on the production of elaborate - usually coloureddrawings of ritual constructions according to textual prescriptions. In the eighth year the students embark on Madhyamaka philosophy - regarded by many as the most prestigious part of the course, not least because it equips the Bonpos to compete with the Gelugpas on their preferred scholarly terrain - and, for the scientific component, techniques for the consecration of stupas. The two main components of the ninth year are cosmology and grammar-specifically, Sanskrit grammar.

The domain of cosmology is intimately related to astrology, and we shall return to it presently. The tenth year is devoted to the study of monastic disciplinary code, while the accompanying science is medicine. As stated above, Tibetan medical training is a lengthy process that is traditionally combined with the study 
of astrology, and this one-year course is designed to familiarise monks with the principles and the associated literature, not to produce practising doctors. The tenth year is the last in which sciences are studied, and the remaining three years are devoted to the study and practice of the higher tantras and, finally, the systems of the "Supreme Way" or "Great Completion," Dzogchen.

Let us return now to the fourth and fifth years of the course. The main morning sessions consist of a study of the Nine Ways of Bon, a system of classification in which all the Bonpo teachings are organised in a ninefold hierarchy; and the fifth year entails a study of the "Stages and the Paths [to Enlightenment]" (salam; sa lam). The following section will examine more closely what it is that students in these two years actually study by way of science.

The subject of elemental divination-Nagtsi-has formed the subject of a number of fine studies, ${ }^{18}$ and since the fundamental principles and techniques used by Bonpos do not differ significantly from those used by the Buddhists, they can be passed over briefly. The following paragraphs will offer a summary of the main treatise on Nagtsi divination studied by aspiring geshes, with particular emphasis on the distinctively Bonpo features of the work. The text is entitled "A Treatise on Elemental Divination according to the "Mirror of the Phenomenal World: the Science of Calculation" (gTsug lag rtsis kyi rig pa snang srid me long las nag rtsis kyi rab tu byed pa). ${ }^{19}$ The author, Khedrub Lungtog Gyatso Chogle Namgyal, was born in Zalmogang (Zal mo sgang), in Eastern Tibet, in 1874. The only information I have been able to find concerning this figure is derived from the four-page biographical introduction that precedes the 2005 Indian edition of his work. ${ }^{20}$ The rather formulaic nature of this preface suggests that little is known about the author. What is at least known is that he served for a time as the Senior Teacher of Yungdrungling Monastery, and the titles of his numerous publications suggest that he was a prolific writer who mastered a wide range of scholarly subjects.

This was the text from which Tenzin Namdak had studied Nagtsi in Tibet. However, it was not among the texts that the Bonpos brought with them into exile, and for many years the geshe curriculum made use of a different manual. In the course of his first return visit to Tibet in 1986 Tenzin Namdak was able to locate a manuscript of this work, and had it printed first in Chengdu and, subsequently, in India.

18. Notably Schuh 1973b; Gyurme Dorje 2001; Tseng 2007. For a recent study of Bonpo pebble divination see Smith 2011.

19. Short title: mKhas grub.

20. Short title: mKhas grub 2005. 
For our present purposes, one of the most interesting aspects of this work is what it tells us about Bonpo beliefs concerning the origins and transmissions of Nagtsi elemental divination. As we have seen, Nagtsi is a Tibetan adaptation of Chinese divination, while Kartsi ultimately derives from the Indian Kālacakra system. According to the Bonpos, however, both traditions come from the Kālacakra, and the Chinese features of Nagtsi are to be understood as a consequence of the roundabout trajectory by which one of the transmissions found its way to Tibet. The Bonpo version of the Kālacakra constitutes the final chapter of the fourth volume (the twentieth chapter overall) of the Ziji ( $g Z i$ brjid), the twelve-volume biography of Shenrab that dates from the fourteenth century. The sutra - for this is how it is classified - bears little resemblance to the Buddhist tantra, and in certain versions of the Ziji it does not even have the title "Kālacakra." 21

The introduction to mKhas grub opens with a few words of homage to the divinity Mawe Senge (sMra ba'i seng ge) before going on to summarise the canonical account of the events preceding the first preaching of the Kālacakra by Shenrab. That episode will be discussed in more detail in the context of the Bonpo Kartsi, to be dealt with below, but for now let us see what Lungtog Gyatso says about the reception and subsequent transmission of the teachings.

"Then the Great Dungsob (gDung sob) and the Victorious One Shākya Senge relayed [the teaching]." 22 This is a reference to the Ziji's account of Shenrab's preaching of the Kālacakra. According to this account, the main recipients of the teaching were four of the Master's most important disciples, who included two of his own eleven sons. One of these was his eighth son, the Great Dungsob, who is better known by the name Mucho Demdrug (Mu cho ldem drug). Of the other two, one was named Lhabu Dampa Togkar (lHa bu dam pa tog dkar). Shenrab instructed this disciple to promulgate these teachings in India in his next incarnation; and indeed Lhabu Dampa Togkar is regarded by Bonpos as a previous incarnation of the historical Buddha Shakyamuni, one of whose epithets is the "Lion of the Shākyas"—Shākya Senge.

The account continues:

21. Whereas in the 1999 Chengdu edition of the Canon the title that appears on the first folio is "The Ritual of the Mighty Kālacakra" (dBang ldan dus 'khor gyi cho ga) (dBang ldan: 591), the concluding line identifies the work as "The Chapter Concerning the Teacher's Establishment of the Precious Doctrine on a Thoroughly Firm Footing," (sTon pas bstan pa rin chen rab tu brten [recte brtan] pa mdzad pa'i le' $u$ ) (dBang ldan: 731); this is much the same as the title it carries in the 2000 Chengdu edition of the Ziji (bsTan pa rin chen: 450) and also in the sixteenth-century manuscript version studied by Snellgrove for the Nine Ways of Bon (Snellgrove 1966: 6).

22. mKhas grub: 438. 
Some argue that there is no connection [between the Buddha Shākya Senge] and [Shenrab] on the grounds that [the former] did not actually meet [the latter], but there is no real objection: the Enlightened One (i.e. Shenrab) gave his authorisation, and through the higher perception of exhaustion of defilement, it had the inherent force of faultless transmission: this is something that cannot be contested. ${ }^{23}$

"Authorisation" in this excerpt is a technical expression denoting the authority to practise and transmit an esoteric teaching that one has received. Thus the Kālacakra was transmitted by Shenrab to the previous incarnation of Shākyamuni in the course of a legitimate initiation, and he carried it with him into his ultimate life on earth. In the next passage the author elaborates on the transmission lines, and emphasises his point that the apparent diversity of the end-points should not obscure their common origin and essence.

The [disciples of Shenrab] who are known as the Six Ornaments [later] spread the Kālacakra teaching through all realms. But prior to that time, in the land of Greater China, the Wise King Kongtse (Kong tse) taught the 360 "calculations of transformation" ('gyur rtsis) on the basis of the teachings of the Man ngag Dus 'khor. This was transmitted to the Scholar Legtang Mangpo (mKhas pa Legs tang rmang po), who promulgated it in Tibet. The Four Sons of the Sciences translated it, but did so into a variety of languages. Nonetheless, however you alter a golden image, its essential material remains nothing other than gold. And so one tradition is not in contradiction with another. ${ }^{24}$

According to Bon tradition, the Four Sons of the Sciences were responsible respectively for the promulgation of Shenrab's teachings on sortilege $(\mathrm{mo})$, calculation (in its broadest sense, tsi; rtsis), religious law (chö; chos, i.e. the Buddhist doctrine) and medicine. It is unfortunate, the author is implying, that the babel of languages into which the teachings were rendered should conceal their essential identity as the teaching of Shenrab Miwo. According to this account, then, Shenrab's teaching of the Kālacakra was the basis for the system of "360 calculations of transformation" promulgated by the Wise King Kongtse. The figure of Kongtse plays an important role in Tibetan accounts concerning divination and certain categories of rituals. As a number of authors have shown, there is little doubt that Kongtse is a Tibetan adaptation of Confucius. ${ }^{25}$

23. mKhas grub: 438 .

24. mKhas grub: 438-439.

25. The most extensive work on the topic of Kongtse is probably Lin 2007, and references to most of the preceding studies featuring this figure can be found here. 


\section{The cosmic tortoise}

One motif that has as much importance in the Bonpo divinatory tradition as it does in Buddhist accounts is the well-known figure of the cosmic tortoise. ${ }^{26}$ The tortoise is central to both certain cosmogonic myths and also to divinatory schemes, and it is worth spending some time to examine the Bonpo assimilation of this motif. In the Buddhist account (which itself has clear Hindu antecedents) Mañjuśrī kills the giant tortoise (in this case, probably a turtle) with a golden arrow so that the flat surface of its upturned carapace can provide a firm foundation for the nascent world. The corresponding account given in Lungtog Gyatso's treatise is as follows:

Then Mawe Senge (sMra ba'i seng ge) in his yellow form embraced the world in his compassion, and emanated a golden tortoise as a foundation, and it lay spreadeagled on its back. Its head pointed to the south and its tail to the north, and its four limbs pointed to the four interstices. It is said to have been the foundation on which Mt Sumeru came into being. From the flesh, the blood, the bodily warmth and the breath of the tortoise there appeared the four great elements; from its twelve outer and inner faculties ${ }^{27}$ there arose the basic cycle of twelve years. From its eight consciousnesses came the eight trigrams, and from its nine orifices the nine magic numbers. Its eight major joints became the eight great planets and its twenty-eight lesser joints became the twenty-eight constellations. There were further manifestations still: from the subtle constitution of its liver, to the east, there appeared the element wood, to which belong the [calendrical animals the] tiger and the hare, the hexagram Zin, and the planet Jupiter; the Pleiades, the lunar mansions Mindruk, Narma, Go, Lag, Nabso, and Gyal, and the six eastern stars. ${ }^{28}$ The element of all these is wood. From the subtle constitution of its heart there came the element fire, to which belong the horse and the snake... ${ }^{29}$

The text goes on to list the corresponding manifestations of the tortoise's organs to the west (lungs) and the north (kidneys), and those in the interstices, along with the associated elements, animals, trigrams and so forth. The section concludes with a list of the "magical numbers" (mewa; sme ba) and the values associated with them, as these associations must be recalled without hesitation

26. For a discussion of a number of Tibetan Buddhist accounts, see Gyurme Dorje 2001: $46 \mathrm{ff}$.

27. skye mched; properly speaking, its five sensory faculties with the five corresponding sensory objects, together with its mental faculty and mental objects.

28. Respectively smin drug, snar ma, mgo, lag, nabs so and rgyal. These are the third to the eighth lunar mansions, corresponding to numbers 2 to 7 , since the first mansion is conventionally identified with a zero.

29. mKhas grub: 439. 
during the performance of divinatory calculations. The introduction closes with summary formulations of such things as the nature of the relationships (friendly, antagonistic, mother/son) between the various elements and closes with the statement that "this is the foundation for all kinds of divination." 30

The entire work is composed in seven-syllable verse, and sections such as this introductory chapter are intended for memorisation so that the student can have the fundamentals of divination at his fingertips - literally: as part of their training, monks are required to draw coloured diagrams of the tortoise as it is described in the text. The essential features of this tortoise are mentally projected onto the hand, with different numbers, elements and directions and the like being accorded fixed positions on the palm and along either side of each digit, so that the diviner's hand becomes an ever-accessible "memory palace" or calculating device of considerable sophistication and accuracy.

As stated earlier, the Bon religion is a complex amalgam of components that probably have very diverse origins in India, China, Central Asia and within Tibet itself. For the Bonpos themselves, the unity of these strands is provided by the belief that they all form part of the teaching of the founder of the religion, Shenrab Mibo, and several canonical works - among the most important of these being the master's twelve-volume biography, the Ziji-are structured in such a way as to reinforce this doctrine of a common provenance. The domain of cosmogony is especially diverse. The best-known Bonpo cosmological work, the Dzöphug ( $m$ Dzod phug), ${ }^{31}$ comprises seventeen chapters, each of which is prefaced with an account of the origins of the universe; but no two accounts are identical. However, the Bonpo canon contains cosmological works other than the Dzöphug, and the versions given by some of these are more markedly different, suggesting the incorporation of quite different traditions. A rough analogy from the Judaeo-Christian tradition would be the book of Genesis, in which two quite different anthropogonic accounts are presented in close proximity without being a cause of consternation for the majority of believers.

Lungtog Gyatso's work opens with an invocation to the divinity Mawe Senge, and a short way into the introduction we find the same divinity emanating the tortoise that is to become the foundation of the world. Mawe Senge, the "Lion of Speech," corresponds very closely in iconography and function with the Buddhist Mañjuśrī, and there can be no doubt about the Buddhist influence upon the composition of this Bon divinity. The author's attribution of the tortoise to the activity of Mawe Senge may be a conscious attempt to align the

30. mKhas grub: 440 .

31. See Karmay 1998 [1975]: 126-132. For an insightful study of the probable Indian antecedents of parts of the Dzöphug see Martin 2000. 
Bonpo version with the Buddhist account, while at the same time maintaining a nominal Bonpo distinctiveness. The Bon canon contains a much older work, the Kun'bum khra bo - of which Lungtog Gyatso was surely aware - in which the cosmic tortoise is framed in a narrative that is much more characteristic of indigenous Tibetan cosmogonic myths. ${ }^{32}$ This account is especially interesting for our purposes insofar as it combines the relatively abstract numerical schemes that characterise the Indian astrological models with a more Tibetan idiom in which every quantity, from the vastest spans of time or the planets down to the minutest second is intimately associated with an elemental being or divinity. The ubiquitous presence of divine agency is especially apparent - and even alarming - in the implication that karma, the law of cause and effect, does not operate by its own intrinsic dynamic but through the activity of divinities whose task it is to ensure that the results of past deeds come to fruition.

The point of departure in this account is not Mawe Senge but an obscure divinity named Künbum Goje (Kun'bum go'byed). The name is not easily translatable, but may be glossed as "the One who Apportions Spaces for All the Hundreds of Thousands." In other words, he is named in terms of his function as a primordial divinity who brings order to the undifferentiated vastness of the universe. Although he is described in Buddhist terms as a sugāta, the entire cosmogonic process is expressed in an idiom that is far more characteristic of indigenous Tibetan myths.

At that time, the sugāta Künbum Goje (Kun'bum go'byed) brought together the sheen of one of his hairs, the spittle of his mouth and the metallic gleam of his fingernails, the warmth of his body and the breath of his mouth, the impurities upon the surface of his body and the radiance of his mind. With them he wrote the Nine Heroic Syllables of the elements on a precious golden tablet. Then he cast the tablet to the ground. In the centre of the golden earth there came into being the foundation for the lives of the world: a yellow tortoise of gold. Its heart was a wish-fulfilling gem, eight-sided and blazing yellow-green. Künbum Goje's son, the emanation of his compassion, named All-Pervading Essence of the Earth, came down to earth from heaven as the lord of that heart. From him there emerged the nine Earth-Pervaders: Sipa Drangyug (Srid pa'brang yag), the General Pervader; Saje Hulu Jamkhyab (Sa rje Hu lu'byams khyab); the Earth-lord ( $s a$ bdag) Bumje Trhikhyab ('Bum rje khri khyab); Sangwa Agchen Khyabpa (gSang ba ag chen khyab pa); the Earth-lord Tsangkün Khyabchen (Tsang kun khyab chen); the Earth-lord Wangkhyabje (dBang khyab byed); Sister Lhamo Tenma (Sring mo 1Ha mo brtan ma); Brother Sala Gönbu (Ming po Sa la

32. The Kun'bum was discovered by a certain Nyagtön Zhönnubum (gNyag ston gZhon nu'bum). Although I am unable to establish precise dates for this figure, he is known to have been a disciple of Guru Nöntse (Gu ru non rtse) who was born in 1136 ( $c f$. Kvaerne 1971: 231). 
mgon bu); and as the manifestation of Samo Thangdeng (Sa mo thang deng) there appeared the one called Nambön Karpo (gNam bon dkar po). He took as his wife Sakhen Mamo (Sa mkhan ma mo), who bore their offspring, the Six Brothers and Sisters. The eight Lords of the Earth, the parents [and their six offspring] held power over the elements of the earth, and they exercised their dominion over the elements of the created universe.

From them there manifested kings who held sway over the circle of the world - the twelve rulers of the phenomenal world, who put forth sixty manifestations, and the 360 further emanations. To carry out their commands there were the Twelve Queens of the Four Times, who put forth 144 manifestations. These were put out as the 360 Gods of the Days (zhag lha), who produced the 720 Gods of the Times (i.e. days and nights); they manifested as the 990 Gods of the Periods (thang lha), who produced the 90,900 gods of the Moments (yud lha), who produced the ten-million-times-onehundred-million Gods of the Seconds (skad lha), ${ }^{33}$ and these put forth a hundred million million ${ }^{34}$ Instants (skad tsam).

Without error or confusion they performed their tasks without transgressing [the limits of] their mansions. And furthermore, the twelve gods who ruled the earth, Sala Gönbu and his ministers, along with their outer circle, the Great Kings who were the Gods of the Law, and their inner circle, the Gods of the Essential Life-force, as well as their four protector divinities: Tiger-skin Quiver Great Man (Tagral Miwoche; sTag ral mi bo che) in the east; Red Bird Lord of the Flock (Bya dmar khyu la rje) in the North; Wild Yak Lord Yagpa Warrior Demon ('Brong rje Yag pa btsan) in the west, and Dragon God King of the Secrets ('Brug lha Gab pa rgyal) in the south. Tsangtsang (Tsang tsang) and his hosts keep watch over our households. Black Sky-dog guards the palace door; Black Hal-dog prevents the movement of corpses; Black Belly-Crawler (Toche Nagpo; 1To'phye nag po) seals the charnel grounds (to prevent vampires from rising); the forty protectors of the elements, and the protectors of the times keep watch over the waxing and waning of the sixty Haughty Ones; the [eight] planets and the [twenty-eight] constellations, thirty-six in all, control the years; the forty protectors of the bodily elements and those who take care of birth-places. These and others in the host of the Lords of the Earth came into being in numbers that surpass comprehension, and provided the foundation for the inhabitants of the phenomenal world. They obeyed the word of Shenrab and performed virtuous actions for the enlightened ones. They brought the elements under their control; they maintained the aeons in an even balance; they acted as the protectors of living beings; they set the sky, the earth and time in order. They kept the transitions of living

33. The English translations given here for these terms are of course impressionistic, and are not intended to correspond to conventional Western units of time.

34. The Tibetan term is tragtrig (khrag khrig). In the section on "large numbers" below, the value of a tragtrig is one hundred million million. However, as the author of that particular section himself warns, the significance of these figures varies from one text to another, and in the present context it is clear that it should be greater than the preceding number of Gods of the Seconds. 
beings smooth. They maintained control over the high, the lowly and the mighty. They repelled the Dü-demons ( $b d u d$ ) and the Sin-demons (srin), dispatching them to their respective demonic realms. They protected the Eternal Bon doctrine; they made manifest the consequences of virtue and $\sin .^{35}$

This, then, is the orderly Bonpo universe, with all its spatial and temporal divisions, its processes of change, the heavenly bodies, the living and the dead, in their proper places, animated or kept in place by a pantheon of gods and elementals who assiduously discharge their allotted duties. This remarkable work, the Kun'bum khra bo, confronts us with a sort of Occasionalist universe distantly redolent of that conceived by Al-Ghazali or Malebranche, in which divine intervention is required to establish causal relations between otherwise impotent mundane phenomena - even to the point of operating the machinery of karma. ${ }^{36}$ But a closer investigation of this universe would take us far from the central concern of the present article, which is to examine Bonpo astrology from two perspectives: the pedagogical environment in which it is transmitted in exile, and the content of the works through which this education is conveyed; and it is to the teaching of astrology proper-Kartsi-that we now turn. The presentation will follow much the same scheme as in the case of Nagtsi, according to the principles set out in the introduction: that is to say, focusing less on actual techniques and performance and rather on the aspect of assimilation in both senses of the term: on the one hand, the distinctively Bonpo formulation of this science and, secondly, the process by which it is transmitted in the context of monastic education.

\section{Kartsi: the Indo-Tibetan astrology of the Bonpos according to Khenchen Nyima Tenzin}

Mention has been made above of the errors that crept into the Tibetan calendrical system and accumulated over the course of time to produce a marked discrepancy between textual prescription and empirical observation. The reason, as we has seen, was the phenomenon of the precession of the equinoxes and the cumulative disparity between the sidereal and solar years. The corrective techniques developed in India were not transmitted to Tibet with the rest of the Kālacakra, and it was left to a few innovative Tibetan scholars to formulate their own compensatory devices. Dieter Schuh's remark that empirical observation of the skies probably played a very small part in the astrological activities of the

35. Kun'bum: $24-26$.

36. A fascinating article by François Chenet (1985) traces the history of Indian beliefs concerning the influence of astrological factors on the operation of karma. 
Tibetans is surely true as a general observation (1973: 20). There were, however, certain notable exceptions, and there is some evidence that two eminent Bonpos were among them. The two in question were Shen Khedrub Tshultrim Gyaltsen (gShen mKhas grub tshul khrims rgyal mtshan, 1783-?) and Khyungtrul Jigme Namkhai Dorje (Khyung sprul'Jigs med nam mkha'i rdo rje, 1897-1956), who both wrote treatises on astrology. Biographical accounts of both these figures refer to their use of a gnomon in order to observe the angle of the shadow cast by the sun at different times of year, and their formulations of a set of calculations whereby to amend the errors in the Kālacakra. The treatise by Tshultrim Gyaltsen was widely used by Bonpos in Tibet, and it constituted the basic text from which Tenzin Namdak studied the subject in his cave retreat. It was not republished in India until 2004, and in the interim the geshe training programme made use of Khyungtrul's treatise, that had been printed as early as 1972. It is now once again the standard training manual used in preference to Khyungtrul's because the mathematical system is said to be more accessible to students. Another treatise that has often been used either as the main course-book or else as a supplement is a work by Khenchen Nyima Tenzin, the twenty-third abbot of Menri monastery.

The main differences between these works seems to lie in the "core" chapters that deal with astronomical computations, and although they clearly merit a proper study, their subject matter is beyond the scope of this article. The sections with which we are particularly concerned here are the introductory chapters that deal with the mythological background and the pedagogical principles, and these seem not to differ significantly from one to another. Since Tshultrim Gyaltsen's work is currently unavailable to me, I shall instead base the following account on Nyima Tenzin's treatise, which I use in preference to Khyungtrul for reason of its greater legibility and clarity of exposition.

Nyima Tenzin's introduction begins with a more detailed account of the original sermon on the Kālacakra. Shenrab descends to earth through the various tiers of heaven:

In the land of Olmo Lungring, in Tazig, on the full moon of the first spring month of a Wood Rat year, the year Gyal (rGyal), he was born as the princely son of Gyalshema (rGyal bzhad ma), a manifestation of the goddess Jamma (Byams ma). ${ }^{37}$

Several comments are in order at this point. The Bonpos celebrate the birthday of their founder in the twelfth Hor (Mongolian) month, usually corresponding to January, since in the Bonpo calendar this is when the year begins-a more archaic tradition known as the "agricultural new year" (sonam losar; so nam lo

37. mKhan chen: 309. The Bonpo goddess Jamma corresponds in certain respects to the Buddhist Tārā. 
gsar) that is celebrated in many parts of Tibet in tandem with the modification introduced in the thirteenth century under the Mongols. We also note that the year in question, Wood Rat, is the first year in the Chinese sexagenary cycle and not that of the Kālacakra, which begins three years later. Other distinctive features of the Bonpo calendar will become apparent presently.

When [Shenrab] was in his twelfth year, the Tenma (brTan ma), the goddess of the earth, offered him a golden vase full of nectar as an auspicious object, and invited him to the great palace of Wangchen (dBang chen), the king of the earth-lords, in Upper Sum in Mönyul, to the south of Olmo Lungring, in Tazig. Here, Tsangkun Wangchen (gTsang kun dBang chen) offered him a golden wheel with a thousand spokes, ornamented with a sun-and-moon jewel, and besought him to promulgate the doctrine.

So in order to preach the doctrine he ordered that a citadel of the mighty Kâlacakra should be built. The project was assisted by the gods, the serpent-spirits, and humans, and the king of crafts Garma Lisho (Gar ma li sho) and [craftsmen known as] the Six Ornaments who Bring Beauty to the World built: a square perimeter wall, each side of which measured 140 fathoms, and in the middle of it a palace named Barab Yongdu citadel (gsas mkhar ba rab yongs'dus). They brought together examples from the architectural styles of the gods, demi-gods, serpent-spirits, and the divinites of the sin, si, kö and cha (srin, srid, bskos, phya $[\text { sic }]^{38}$ ) classes. ${ }^{39}$

In the centre was the mandala of the gods, which was the Buddha-field of the Kâlacakra; the middle space was an enclosure containing a great variety of desirable things for offerings; the outer space was a garden with the hexagrams, the elements, the magic numbers; the cycle of twelve years and other such things; the seventy cosmic protectors, and the kings of the four quarters. But their wondrous beautiful palaces and realms, and the [realm of the] 33 gods, could not be compared to it.

On the day of the full moon of a Water Pig year, in the month named Nag, that Protector of a Hundred Teachers (i.e. Shenrab), in response to the request from a circle [of eight shen priests including] Tshangpa Tsukphü (Tshangs pa gtsug phud) and a huge host of countless millions of other beings, represented by their chiefs, preached the Kālacakra, a Bon teaching belonging to the "Treasury" category. ${ }^{40}$

...The [Kālacakra] cycle was entrusted to Serthub (gSer thub; Kankamuni) and Ösung ('Od srung; Dīpamkara) as a treasure of the doctrine, and it spread thence vastly in

38. The word cha, when denoting a category of divinities, is properly spelt phywa.

39. An illustration of the Bonpo version of the Kālacakra mandala is given in Namdak et al. 2000: 4 .

40. mTho thog spyi rgyug mdzod kyi bon. This is the highest of a five-fold scheme of classification known as the "Four Portals and the Treasury, Five in All" (Bon sgo bzhi mdzod lnga). 
Shambhala, in Tazig, ${ }^{41}$ and after that it was transmitted to Dungsob. ${ }^{42} \mathrm{He}$ later started the "Doctrine of the Speech" of the Teacher Shenrab. He was one of thirteen to put together the teachings of the Teacher Shenrab and add commentaries. Then Dungsob systematised it and taught it to the six ornaments of scholarship, the translators, with commentaries and supplementary texts. Those six great translators translated it into the languages of Zhangzhung, India and China, and caused the doctrine to flourish. Subsequently the great teacher Tsilu (Tsi lu) ${ }^{43}$ transformed it into a Buddhist system. ${ }^{44}$

The author then goes on to trace the transmission of the teaching along a succession of Bonpo masters, ending with his own teacher "from whom I received the teachings in full, like the contents of one vase being poured into another."

Against this background of an uncompromisingly Bonpo formulation of the Kālacakra's origins and transmission, we come to an introductory chapter entitled "A brief presentation of the essential preliminary steps." ${ }^{45}$ A detailed summary of this chapter is worthwhile for two reasons. First, because it contains sections that feature distinctively Bonpo elements - such as a certain system for naming the years - and secondly because it sets out the fundamental concepts and techniques that monks are required to master during their astrological training. At the end of this article I shall offer some tentative conclusions concerning the devices that have been used in the Bonpo assimilation of astrology. To anticipate these conclusions, although the "Bonpo" aspect is obvious in this text it is by no means pervasive, and in certain cases seems to have been added, sometimes almost perfunctorily, to an essentially nondenominational scientific discourse. In most of following subsections it is quite likely that there is nothing specifically Bonpo that one would not find in a comparable Buddhist treatise, but this would need to be determined by a textual comparison of the sort that is beyond the scope of the present account. Nevertheless, since part of the object of this study is to outline the subject matter that prospective geshes study, whether distinctively Bonpo or not, the contents of the chapter will be described briefly.

41. For the Bonpos, the mythical land of Shambhala that is associated with the Kâlacakra in Buddhist literature is identical with their own sacred land of Olmo Lungring (Ol mo lung ring), located in Tazig (broadly, Central Asia).

42. That is, Mucho Demdrug (Mu cho ldem drug), the eighth of the eleven sons of Shenrab.

43. "Tsilu" is a reference to the tenth-century Indian pandit Cilupa. Cilupa's role in the transmission of the Kālacakra is championed by one of the two main Kālacakra traditions, the Ra (Rwa lugs). The other tradition, the Dro ('Bro lugs), accords this status to a figure named Kālacakrapāda the Elder.

44. mKhan chen: 309-310.

45. Nyer mkho sngon'gro'i rim pa mdo tsam bshad pa. 
As in the case of the manual of elemental divination, it is expected that monks will memorise the chapters (and others besides) in order to have ready access to the essential tools. The chapter contains no subdivisions, but may be broken down into its constituent parts for the sake of convenience.

\section{Multiplication tables}

These are known as the thagu (mtha'dgu), literally "bounded by nine," and the form they take is quite different from that of the multiplication tables taught in the Western pedagogical traditions. The structure is as follows: "one nine or nine ones make nine; two nines or nine twos are eighteen; three nines..." and so forth, up to nine nines - the highest calculation in the section, whence the name of the series. After the nines have been exhausted, the series moves down to eight, with eight times eight being the highest in this table. Thus the entire sequence ends with: "one two or two ones are two; two twos are four; one one is one." 46

\section{Direction of numbering}

"When writing counting or adding numbers, one should do so from right to left." 47

The syllables jung, me and da (byung, me, zla) are "code-words" or epithets (on which more will be said below) corresponding respectively to the numbers 5,3 and 1. Thus if we were to encounter the sequence of syllables jung me da in a formula we should understand them to signify not 531 but 135 .

"When multiplying, dividing or subtracting, one should do so from left to right." 48

Then follows a series of basic procedural rules that are largely self-explanatory.

The zero of the number that is multiplying [another] should be placed at the end of the row; the zero of a divisor should block the end of the lower row. If a number that is to be multiplied is empty there can be no multiplication. If the number that is multiplying is empty, then everything must be nil. ${ }^{49}$ If you multiply by one, there is no increase or diminution; if you multiply by two or other numbers, the increase amounts to adding the figure to itself that number of times. A zero that occupies a

46. mKhan chen: 311-312.

47. mKhan chen: 312 .

48. mKhan chen: 312 .

49. dpyi, literally "wiped out." 
place in the middle or at the end of a divisor has no power to divide or do anything except occupy its position. ${ }^{50}$

The section then outlines the principles of single and multiple division before closing with the rule that "a zero may not be placed at the beginning of a row of numbers."

This entire summary of the principles of arithmetic is covered in precisely eight lines of the book. Such a terse presentation is clearly unusable without extensive commentary, but it accords with the Tibetan pedagogical method whereby students memorise a text in such as way that it is always accessible as a mnemonic device that can itself evoke the necessary details.

\section{Astronomical sets and time values}

mKhan chen then goes on to set out certain basic units of time:

The days (or planets) and the karanas comprise sevenfold cycles; there are twentyseven of each of the two [kinds of] "stellar encounters;" there are sixty "hours" [in a day and sixty] "minutes" in an "hour;" and a variety of lesser measure measurements (chashe; cha shas) in one breath. ${ }^{52}$

While the seven planets have considerable importance in astronomical reckoning, the corresponding period, the week (known as a "sevenfold" or a "planetary cycle") does not feature significantly as a temporal measure outside a modern urban context. In rural Tibet, time is usually reckoned in days and months. As for the karanas, the Kālacakra lists eleven. However, four of these are "permanent" (tagpa; rtag pa) and seven "shifting" (phowa; pho ba), and it is therefore likely that the above excerpt denotes the former category.

The twenty-seven "stellar encounters" (karjor; skar sbyor) are divided into two categories: "major conjunctions" and "minor conjunctions" (tröchen, tröchung; phrod chen, phrod chung). A major conjunction denotes the coincidence of one of the twenty-seven lunar mansions with one of the nine planets. Each of the conjunctions has a name and certain characteristics. But there are only twenty-seven conjunctions, because the same effect may be produced by seven different combinations of mansions and planets. Thus the conjunction named "spear" is produced by the coincidence of planet Moon with the lunar mansion named Möndre (Mon gre), the planet Jupiter with the mansion Gyal (rGyal),

50. mKhan chen: 312 .

51. As above, the translations in inverted commas are not meant to correspond to the conventional understanding of these terms.

52. mKhan chen: 312 . 
and the planet Mercury with the mansion Narma (sNar mar), as well as four others. A minor conjunction, by contrast, is the outcome of the combination of the element that is linked with the planet, and the element linked with the lunar mansion. Thus the conjunctions of the elements of the components of the three pairs in the examples cited above would be different from the result of the conjunction produced by the pairs alone, and the nature of the relationship between these two kinds of conjunction is one of the many factors to be taken into consideration when producing almanacs and horoscopes.

As for the temporal subdivisions of the day, the word "hour" has been placed in inverted commas since it represents a sixtieth, not a twenty-fourth, part of the day, though it should be noted that the same term is used for the modern Western hour - chustö (chu tshod), literally "water measure," since it derives from the use of the Chinese clepsydra. Similarly, although a "minute" in this extract is a sixtieth of an hour, it obviously does not have the same value as a Western minute.

\section{Synonyms for arithmetical processes}

A list of synonyms is given for the actions of multiplication, division, addition and substraction, with occasional helpful explanations for the terms. Thus one of the terms for "divide" is dor ('dor), to "throw away;" the reason for this, the author states, is that when we divide a number, the remainder is more pertinent to the astronomical calculation we are performing than the actual result of the sum — which we frequently discard, dor. ${ }^{53}$

\section{Names of large numbers}

Although there are various numbering schemes that do not agree with one another, our author says, this is the list that is given by the Omniscient Nyamme Sherab Gyaltsen, the fourteenth-century reformer of Bon and the founder of Menri monastery, in one of his treatises. There are sixty named numbers: one, ten, 100, and up to a million, ten million and a hundred million. (Indeed, as the author alerts us, the terms for a million and ten million (saya; sa ya and jewa; bye ba respectively) are often reversed. This sequence of nine numbers is followed by another twenty-five, after which we are told that "each of these has [a form called] 'great'(che)." The "great" form is ten times larger than the simple form. Thus a therbum (ther'bum) is one American billion (a thousand million) and a therbumche (ther'bum che) is a British billion (a million million, the American trillion). The first two sequences therefore contain numbers with

53. mKhan chen: 312 . 
a total of 59 different values. "And finally there is the sixtieth one, which is the so-called 'countless' (drangme; grangs med)," a number that would be a digit followed by fifty-eight zeroes. ${ }^{54}$

\section{Names of small numbers}

Whereas the high numbers given in the preceding list are largely academic, since they do not feature much in astrological literature, the next section gives "code names" of lower numbers that students must learn well, since they are used very extensively. Most of them probably derive from Indian conventions. Thus the terms "moon," "hare," "form," "rhinoceros," "the one with white light" are all epithets of the number one, in certain cases by extension of epithets for the moon, which is solitary. ("Rhinoceros" is a synecdochic reference to the Indian one-horned rhinoceros). The list extends up to number thirty-two, but some of the intervening numbers higher than ten have no epithets at all. The relevance of these names will be illustrated presently. ${ }^{55}$

\section{Classification of the years and months}

The section on the year begins with a series of definitions and epithets for the year:

The twelve signs of the zodiac, the two solar transits, the passage of the sun around the lunar mansions, the period covered by spring, summer, autumn and winter - this is what is meant by the term year. "Self-protecting," "forsaker," "basis of counting," "the seasons" (lit. "time-joints"), "month-garland," "that which is to be counted," "time-component," "never-ending"- these are names for the year. ${ }^{56}$

This is followed by the list of twelve animals and five elements, and the fact that they can be combined to produce a cycle of sixty. The author then goes on to cite a passage from a work entitled "the Sutra of the Purification of the Yen Heavens," (gYen khams sel ba'i mdo), ${ }^{57}$ which gives a list of names for each of the years in the sexagenary cycle. While this is of course the same principle as that employed by the Kālacakra, the list differs in two significant respects. First, it follows the Chinese scheme insofar as the first year is identified with the Wood Rat year, rather than the Fire Hare of the thirteenth-century Sakya-Mongol

54. mKhan chen: 312-313.

55. mKhan chen: 313 .

56. mKhan chen: 313 .

57. Although it is frequently cited by Bonpo authors, this work has apparently been lost (Tenzin Namdak, personal communication). 
adaptation; and more interestingly, the list of names is different from those of the Kālacakra. The following table, which lists the first sixteen "Bonpo" names beside those of the Kālacakra with the corresponding years from the Chinese sexagenary cycle, will serve as an illustration of the difference. ${ }^{58}$

\begin{tabular}{|l|l|l|l|}
\hline & Chinese sexagenary cycle & Kālacakra name & Bonpo name \\
\hline 1 & Wood Rat & Mig dmar & Byung ldan \\
\hline 2 & Wood Ox & Khro bo & rDzogs pa \\
\hline 3 & Fire Tiger & Zad pa & Rab'bar \\
\hline 4 & Fire Hare & Rab'byung & sByin'gyur \\
\hline 5 & Earth Dragon & rNam'byung & dPa'bo \\
\hline 6 & Earth Snake & dKar po & Myong ba \\
\hline 7 & Iron Horse & Rab smyos & Kun rdzogs \\
\hline 8 & Iron Sheep & sKyes bdag & 'Bras bdag \\
\hline 9 & Water Monkey & Ang gi ra & mThong ldan \\
\hline 10 & Water Bird & dPal ldong & mChog can \\
\hline 11 & Wood Dog & dNgos po & Phan bde \\
\hline 12 & Wood Pig & Na tshod ldan & Kun dha \\
\hline 13 & Fire Rat & 'Dzin byed & 'Bras skyed \\
\hline 14 & Fire Ox & dBang phyug & Ru ldang \\
\hline 15 & Earth Tiger & 'Bru mang po & Sa'dzin \\
\hline 16 & Earth Hare & Myos ldan & Myos rgyal \\
\hline
\end{tabular}

Although the two sets of names are very obviously different, it is worth noting that one of the syllables in certain pairs - in this excerpt, numbers 8 and 16-is the same. The names from the "Sutra of the Purification of the Yen Heavens" are clearly not alternative translations from the original Sanskrit of the Kālacakra, and in the absence of further research there is little point in speculating on their provenance.

After a full listing of the Kālacakra names, the section goes on to deal with the definitions and various names of the seasons, before closing with an elaborate list in which each of the months in the year is identified by ten terms: 1. the Zhangzhung language name, 2. the Mongolian month number, 3. the Sanskrit name, 4. the sign of the zodiac, 5. the Chinese name, 6. the system of Chinese (i.e. elemental) divination, 7. the seasonal division into thirds, 8. the corresponding "link" in the twelve-fold nexus of dependent origination, 9. lunar

58. mKhan chen: 314 . The transliterated forms of the names alone are given here, since the phonetic renderings would add little to the comparison. 
mansion, 10. epithet (rtags ming, lit. "given name"). From the perspective of the Bonpos, perhaps the most significant thing about this sequence is the addition of a name in the Zhangzhung language. Whereas the authenticity of Buddhist works is considered to lie in their having been translated from a Sanskrit original, for the Bonpos the corresponding language is that of Zhangzhung, an area corresponding to western Tibet and parts of Central Asia that is seen as the heartland of the religion. The fact that the names are simply ordinal numbers in the Zhangzhung language does, however, suggest that the author has formulated them himself rather than drawn them from a more venerable source.

Thus the first month is identified as: 1. dari tigzhi (zla ri tig zhi: "first month"); 2. First Mongolian month; 3. Māgha; 4. the Vase (i.e. Aquarius); 5. yi yue (dbyi yol: "first month"); 6. Tiger month; 7. first spring month; 8. Formation; ${ }^{59} 9$. tapa (rta pa, the ninth mansion); 10. Illusory Austerity (cho'phrul dka 'thub) ${ }^{60}$

After listing the association of the months with other quantities such as the elements and the senses, the chapter turns its attention to the seven planets as well as Rāhu and the comet Encke, and lists the numerous names and epithets by which each is known. ${ }^{61}$ Then follow the lunar mansions, along with the explanation that though there are 27, the mansions Drozhin (Gro bzhin) and Jizhin (Byi zhin), which both conventionally carry the number 21, may be treated separately (following the Chinese, rather than the Indian, convention) to give a total of 28 .

The chapter closes with a list of the 30 lunar days, drawing on the same text cited above (the "Sutra of the Purification of the Yen Heavens") to name and briefly describe the "day-god" (tshela; tshes lha) associated with each, as well as the divinities of other units of time. It remains to be established whether these curious entities bear any resemblance to those of Tibetan Buddhist works such as the White Beryl, or whether they belong to an entirely independent Bonpo tradition. ${ }^{62}$

Although they certainly merit closer comparative study, the remaining chapters of mKhan chen will not be dealt with here, partly for reasons of space but also because they deal with the actual procedures for calendrical and astrological calculations, rather than the theoretical and pedagogical background that is our main concern.

59. In the twelvefold cycle of interdependent origination, Formation (Tib. 'du byed; Sk. samskāra) is the second in sequence, following Ignorance.

60. mKhan chen: 315 .

61. mKhan chen: $316-317$.

62. It may be noted that Desi Sangye Gyatso acknowledges his debt to Bonpo astrological treatises in his compilation of the White Beryl (Gyurme Dorje 2001: 17). 


\section{Conclusion}

The calendrical, astrological and divinatory systems of Tibet are a composite of influences from adjacent regions, notably India, Central Asia and China. The imported traditions were transformed in varying degrees and at different times, but generally in such a way as to represent some aspect of the authority, whether religious or political, that was controlling the science in question. The example of the ninth-century pillar treaty revealed the Tibetans'exceptional adoption of a Chinese scheme of dating in order to express the equal status of their nation; an international context in which the usual twelve-year cycle, probably borrowed from Central Asia, would have seemed too parochial. The thirteenth-century formulation of the Sakya-Yuan calendar was a delicate balancing act between highlighting areas of commonality between Tibet and China, and at the same time favouring aspects of the Kālacakra in order to emphasise Tibet's distinctiveness. Later, the errors that resulted from an uncritical acceptance of the Kālacakra were tolerated because of the perceived inseparability of the system from the infallible Buddhist doctrine; and while the corrections that were subsequently made were effected for practical reasons, the modifications themselves came to be inextricably associated with particular religious or political entities, such as the Ganden Phodrang (dGa'ldan pho brang) government established by the Fifth Dalai Lama in the seventeenth century. Such investment of collective identity in a particular scientific model is something that has continued into recent times in Tibet: Jacqueline Hobbs gives the example of different Tibetan monasteries vying with one another over the relative accuracy of their respective calendars, a tension that is particularly marked in the case of the resistance shown by eastern Tibetan monasteries to the cultural and scientific hegemony of Lhasa. ${ }^{63}$

Adherence to a particular calendrical scheme need not be primarily a matter of accuracy. Elsewhere I have described the case of a Himalayan community that maintains its own unique system of measuring time. The scheme is clearly based on the standard Tibetan model that is prevalent in the general area, but the year starts two months earlier and each month has exactly thirty days, with no omissions or intercalations. The inevitable disparity is rectified each year in the course of a simple ceremony when the local date is readjusted to that of the official Tibetan calendar. ${ }^{64}$

Whereas our knowledge of Tibetan astrological sciences - and the sectarian issues surrounding them - is based on the study of works produced in a Buddhist environment, the field of Bonpo astrology remains largely unexplored. The very preliminary nature of the present study does not equip us sufficiently to give a

63. Hobbs 2012: 157.

64. Ramble 2002: 80-81. 
comprehensive definition of Bonpo astrology, but it is nevertheless possible to make certain observations by way of a tentative conclusion. To begin with, the relationship between Bon and Buddhism in the arena of astrology is likely to exhibit much the same features as we find in other arenas: reciprocal borrowings, divergences in traditions that were once fully shared, substitution of names and so forth. If we are to look for anything distinctively and originally Bonpo in this domain it may be that it is to be found in the extraordinarily rich pantheon of divinities that govern every unit of time, space and activity in the universe. It is likely to have been from this rich source that Desi Sangye Gyatso recruited the "earth lords" who feature so prominently in his White Beryl, though on his own account there may have been other borrowings besides. This Bonpo stratum would therefore be at the level of cosmology rather than calculation, though the Buddhist avatars of these gods may not have inherited the same degree of agency attributed to them in Kun'bum.

As for the former, the geshe curriculum designed by Tenzin Namdak exhibits the eclecticism characteristic of Bon as a whole. In particular, the incorporation of sciences such as astrology in the programme stands in contrast to the corresponding curriculum of the Gelugpa school, which eschews the sciences in favour of a more scholastic orientation. As far as the textual tradition of Bonpo astrology is concerned, focusing on the textbooks of the geshe course allows us to see what exactly it is that the monks study, and the degree to which the knowledge they acquire can be said to be distinctively Bonpo. Reference was made above to Dieter Schuh's observation that there is nothing intrinsically Buddhist about Sino-Tibetan elemental divination, and the assimilation of the practice entailed significant adaptation-reformulation of the rituals as tantric performances, insertion of Buddhist formulae and divinities, and so forth. ${ }^{65}$ Apart from the intriguing cosmological features mentioned above, the Bonpo features of the works are relatively superficial. Broadly, there are two ways in which the sciences of astrology and divination that have been touched on here may be said to be Bonpo: on the one hand, the system of calculation may have been developed by a Bonpo scholar. This appears to have been the case with certain works such as the astrological treatise Khyung sprul, though this would need to be determined by a systematic comparison of his mathematic procedures with those of better-known works by Buddhist scholars. The second strategy of assimilation is to adopt a nomenclature that is somehow emblematic of the tradition in question without affecting the underlying structures. This is common practice when Bonpos and Buddhists borrow from each other and change little except the names of the divinities. Examples of this procedure that

65. Schuh 1973a: 17. 
we have seen in the texts examined include the list of Bonpo names for years in a sexegenary cycle attributed to a lost tantra (the "Sutra of the Purification of the Yen heavens"), and the straightforward translation of ordinal numbers of months into the Zhangzhung language.

The third, and most significant, method of assimilation noted above was the narrative of a charter myth that establishes the Bonpo antecedents of the science in question, whether Kartsi or Nagtsi. The two myths that were engaged for this purpose were the Bonpo versions of the Kālacakra and the story of the cosmic tortoise. Both the main textbooks considered here, Lung rtogs and mKhan chen, legitimise their subject matter by prefacing it with a summary account of the origin and transmission of the Kālacakra. Within the space of two pages we learn the essential: that the Kālacakra was originally taught by Shenrab; that both Kartsi and Nagtsi are ultimately derived from this teaching; and that if the Buddhist version bears similarities to the Bonpo one, that is because they have the same point of departure.

But what is most striking, perhaps, is the lightness of this indigenising touch. The evocation of Shenrab's preaching of the Kālacakra is a rather perfunctory gesture of appropriation, since nothing else from the original text finds its way into the main chapters of either Lung rtogs or mKhan chen. (As noted earlier, the canonical work itself seems in some ways to be a token Bonpo appropriation of the institution of the Kâlacakra, since its resemblance to the Buddhist work is little more than nominal.) The evocation of the tortoise in Lung rtogs also has something slightly dutiful about it. Kun 'bum contains a version of the myth that is unquestionably distinctively Bonpo in its form and content. But Lung rtogs eschews this version in favour of an extremely brief allusion to an unremarkable, rather generic, account, in which the only Bonpo feature is the name of the divine protagonist, Mawe Senge, who corresponds most closely to the Buddhist Mañjuśrī. Neither of our two authors, Khedrub Lungtog Gyatso or Khenchen Nyima Tenzin, goes to a great deal of trouble to develop a hypertrophied Bonpo identity in these treatises; instead, the reader is left with the impression of two scholars who have little time for identity politics and are impatient to get on with the serious business of dispensing knowledge.

\section{BIBLIOGRAPHIE}

Sources in Tibetan

bsTan pa rin chen 
bsTan pa rin chen rab tu brtan pa'i mdo (2000 edition). In'Dus pa rin po che'i rgyud dri ma med pa gzi brjid rab tu'bar ba'i mdo zhes bya ba, vol. 4. Lhasa, Bod ljongs bod yig dpe rnying dpe skrun khang: 450-555.

dBang ldan

dBang ldan dus kyi'khor lo (1999 edition). In Theg chen g. yung drung bon gyi bka"gyur, vol. 17. Khreng tu'u, Kun grol lha sras mi pham rnam rgyal: 591-731. dPal ldan

dPal ldan khri brtan nor bu rtse phyag btab nas bgrang bya nyer lnga'khor ba'i dran deb bzhugs// (2012). ("Commemoration volume for the twenty-fifth anniversary of the foundation of Palden Triten Norbutse Monastery.") Anonymous unpublished draft.

Dung dkar tshig mdzod

Dung dkar Blo bzang'phrin las (2002). Dung dkar tshig mdzod chen mo. Beijing, Krung go'i bod rig pa dpe skrun khang.

gShen rtsis

gShen mKhas grub Tshul khrims rgyal mtshan (1973). gŚen gyi rtsis gsar rnam dag las: 'byun rtsis kyi skor'go 'grel bśad bcas kyi gsun pod. Writings on astrological and calendrical calculations by Gśen Mkhas-grub Tshul-khrims-rgyal-mtshan together with the Nag rtsis of Khyun-sprul'Jigs-med-nam-mkha'i-rdo-rje. Reproduced from manuscripts and lithographic prints from the library of Dpalldan-tshul-khrims by Sonam Dakpa. Ochghat, Tibetan Bonpo Monastic Centre.

Khyung sprul

Khyung sprul'Jigs med nam mkha'i rdo rje (1972). dPyad gsum dag rtsis bskal srid dus'khor. Khyung-sprul'Jigs-med-nam-mkha'i-rdo-rje on Calendrical Calculations and Astrology. Reproduced by Tenzin Namdak by photographic process from the lithograph edition printed in Delhi about 1950. Dolanji, Tibetan Bonpo Monastic Centre.

Kun'bum

Kun'bum khra bo (1999 edition). In Theg chen g. yung drung bon gyi bka"gyur, vol. 167. Khreng tu'u, Kun grol lha sras mi pham rnam rgyal.

mKhan chen

mKhan chen Nyi ma bstan'dzin (2011 edition). rTsis kyi legs par bshad pa snang srid gsal ba'i sgron me ngo mtshar'od zer'bum ldan. In Gangs ti se bon gzhung rig mdzod dpe tshogs, deb bzhi ba, bZo rig dang rtsis kyi skor. Beijing, Mi rigs dpe skrun khang: 305-436.

mKhas grub 2005

mKhas grub Lung rtogs rgya mtsho (2005 edition). gTsug lag rtsis kyi rig pa nag rtsis snang srid me long dang/'bras rtsis bden don snying po. Dolanji, Bon Dialectic School.

mKhas grub

mKhas grub Lung rtogs rgya mtsho (2011 edition). gTsug lag rtsis kyi rig pa snang srid me long las nag rtsis kyi rab tu byed pa. In Gangs ti se bon gzhung rig mdzod dpe tshogs, deb bzhi ba, bZo rig dang rtsis kyi skor. Beijing, Mi rigs dpe skrun khang: 437-640. 


\section{Sources in European languages}

Bacot, Jacques, Thomas, Frederick W. and Toussaint, Charles (1940). Documents de Touen-Houang relatifs à l'histoire du Tibet. Paris, Librairie Orientaliste Paul Geuthner.

Blondeau, Anne-Marie (1984). “Le 'découvreur' du Mani bka'-'bum était-il bon-po?” In Ligeti, Louis (ed.), Tibetan and Buddhist Studies. Budapest, Akadémiai Kiadó, vol. 1: 77-123.

Cabezón, José Ignacio, and Jackson, Roger R. (1996). Tibetan Literature: Studies in Genre. Ithaca, Snow Lion.

CECH, Krystyna (1986). "History, Teaching and Practice of Dialectics According to the Bon Tradition.” Tibet Journal, vol. 11, no. 2: 3-28.

Chenet, François (1985). "Karma and Astrology: An Unrecognized Aspect of Indian Anthropology." Diogenes, vol. 33: 101-126.

Cornu, Philippe (2009). L'Astrologie tibétaine. Paris, Alexandre Trédaniel.

Gurung, Kalsang Norbu (2009). "The Role of Confucius in Bon Sources: Kong tse and his Attribution in the Ritual of the Three Headed Black Man." In Dotson, Brandon et al. (eds), Contemporary Visions in Tibetan Studies: Proceedings of the First International Seminar of Young Tibetologists, London, 9-13 August 2007. Chicago, Serindia Publications: 257-279.

Gyurme, Dorje (2001). Tibetan Elemental Divination Paintings. London, John Eskenazi.

He, Xiaoqing (2012). A Preliminary Study of the Ritual of "Three-Headed Black One» (Mi nag mgo gsum), with particular reference to two manuscripts from Mustang and one bKa'rten text. MPhil thesis, University of Oxford.

Henning, Edward (2007). Kälacakra and the Tibetan Calendar. New York, Columbia University Press.

Hoвbs, Jacqueline (2012). When the "Milkbird" Comes: Amdo-Tibetan Constructions of Time in Qinghai and Gansu Provinces, the People's Republic of China. PhD thesis, University of Cambridge.

Karmay, Samten G. (1972). The Treasury of Good Sayings: A Tibetan History of Bon. London, Oxford University Press.

Karmay, Samten G. (1998). The Arrow and the Spindle: Studies in History, Myths, Rituals and Beliefs in Tibet. Kathmandu, Mandala Book Point.

Karmay, Samten G. and Watts, Jeff (eds) (2007). Bon: The Magic Word. New York, Rubin Museum of Art.

KARMAY, Samten G. ([1975]1998). "A General Introduction to the History and Doctrines of Bon." In The Arrow and the Spindle: Studies in History, Myths, Rituals and Beliefs in Tibet. Kathmandu, Mandala Book Point: 104-156.

VAN DER KUIJP, Leonard W. J. (1996). “Tibetan Belles-Lettres: The Influence of Daṇdin and Kșemendra.” In Cabezón, José Ignacio, and Jackson, Roger R. (eds), Tibetan Literature: Studies in Genre. Ithaca, Snow Lion: 393-410.

Kvaerne, Per (1971). "A chronological table of the Bon po. The bstan rcis of Ni ma bstan “jin.” Acta Orientalia, vol. 33: 205-282. 
Kvaerne, Per (1995). The Bon Religion of Tibet: The Iconography of a Living Tradition. London, Serindia.

LAufer, Berthold (1913). "The Application of the Tibetan Sexagenary Cycle." T'oung Pao, vol. 14: 569-596.

Lin, Shen-yu (2007). "The Tibetan Image of Confucius.” Revue d'études tibétaines, no. 12: 105-129.

Macdonald, Ariane (1971). "Une lecture des Pelliot tibétain 1286, 1287, 1038, 1047, et 1290: essai sur la formation et l'emploi des mythes politiques dans la religion royale de Sron-bcan sgam-po." In Études tibétaines dédiées à la mémoire de Marcelle Lalou. Paris, Libraire d'Amerique et d'Orient Adrien Maisoneuve: 190391.

Martin, Dan (2000). “Comparing Treasuries: Mental States and Other mDzod phug Lists and Passages with Parallels in Works by Vasubandhu and Asanga, or in Prajñāpāramitā Sūtras: A Progress Report.” In Karmay, Samten G. and Nagano, Yasuhiko (eds), New Horizons in Bon Studies. Proceedings of a Conference Held in Osaka, August 1999. Osaka, National Museum of Ethnology.

Namdak, Tenzin, Nagano, Yasuhiko and Tachikawa, Musashi (2000). Mandalas of the Bon Religion. Senri Ethnological Reports 12. Osaka, National Museum of Ethnology.

Pelliot, Paul (1913). "Le cycle sexagénaire dans la chronologie tibétaine." Journal asiatique, vol. 1: 633-667.

Ramble, Charles (2002). "Temporal disjunction and collectivity in Mustang, Nepal." Current Anthropology, vol. 43, supplement, August-October: 75-84.

Sснин, Dieter (1973a). Untersuchungen zur Geschichte der tibetischen Kalenderrechnung. Wiesbaden: Steiner Verlag.

SchuH, Dieter (1973b). "Der chinesische Steinkreis. Ein Beitrag zur Kenntnis der sinotibetischen Divinationskalkulationen." Zentralasiatische Studien, vol. 7: 353-423.

SchuH, Dieter (2008). Review of: Janson, Svante (December 2007). "Tibetan Calendar Mathematics." Internet publication on the server of the Department of Mathematics, Uppsala University; Dershowitz, Nachum and Reingold, Edward M. (2008). Calendrical Calculations. Third Edition. Chapter 19, "The Tibetan Calendar," and p. 435-437. Cambridge, New York; Henning, Edward (2007). Kālacakra and the Tibetan Calendar. New York, Columbia University Press. Zentralasiatische Studien, vol. 77: 205-242.

Sмiтн, Alexander K. (2011). "Remarks Concerning the Methodology and Symbolism of Bon Pebble Divination." Études mongoles et sibériennes, centrasiatiques et tibétaines, vol. 42: 1-15.

Snellgrove, David L. (1967). The Nine Ways of Bon: Excerpts from gZi-brjid. London, Oxford University Press.

TsEng, Te-ming (2005). Sino-tibetische Divinationskalkulation (Nag-rtsis): dargestellt anhand des Werkes dPag-bsam ljon-šin von Blo-bzan் tshul-khrims rgya-mtsho. Halle (Saale), International Institute for Tibetan and Buddhist Studies.

URAY, Géza (1984). "The Earliest Evidence of the Use of the Chinese Sexagenary Cycle in Tibetan.” In Ligeti, Louis (ed.), Tibetan and Buddhist Studies Commemorating 
the 200th Anniversary of the Birth of Alexander Csoma de Körös. Delhi, Munshiram Manoharlal: 341-361.

YAmaguchi, Zuiho (1989). "The Significance of Intercalary Constants in the Tibetan

Calendar and Historical Tables of Intercalary Months." In Shoren, I. and Yamaguchi, Zuiho (eds), Tibetan Studies. Proceedings of the Fifth Seminar of the International Association for Tibetan Studies (Narita 1989) Volume 2: Language, History and Culture: 873-895.

YAMAGUCHI, Zuiho (1984). "Methods of Chronological Calculations in Tibetan Historical Sources." In Ligeti, Louis (ed.), Tibetan and Buddhist Studies Commemorating the 200th Anniversary of the Birth of Alexander Csoma de Körös, vol. 2. Budapest, Akadémiai Kiadó: 405-424. 